\title{
Sandstone dykes in the Vang granite, northwestern Bornholm (Denmark)
}

\author{
GERHARD KATZUNG
}

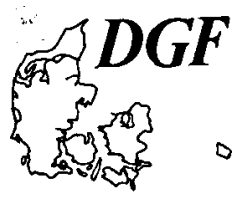

Katzung, G.: Sandstone dykes in the Vang granite, northwestern Bornholm. Bul-
letin of the Geological Society of Denmark, Vol. 43, pp. 51-53, Copenhagen,
1996-07-14. https://doi.org/10.37570/bgsd-1996-43-06

Recently discovered sandstone dykes in the Vang granite of northwestern Bornholm are very similar to those in the Svaneke granite nearby Listed, with regard to strike direction and fillings.

Gerhard Katzung, Institut für Geologie und Paläontologie der Universität, Friedrich-Ludwig-Jahn-Straße 17 A, D-17489 Greifswald, Germany, March 4th, 1996.

Clastic dykes are known from the basement of NE Bornholm since the last century (see Ussing 1899). The most famous outcrops are situated nearby Listed, on the Gule Hald peninsula (Milthers 1930). Fillings consist of greyish to brownish-green, medium to coarse-grained, non-bedded sandstones with chlorite matrix. Detrital composition, inclusions of white, finegrained quartz sandstones, and the occurrence of glauconite point to an early Cambrian age of origin (Brunn-Petersen 1975).

During structural research in the Ringebakke quarry northeast of Jons Kapel, near the west coast of Bornholm (Fig. 1), similar dykes have been recognized last summer in the Vang granite. Their fillings correspond completely to those of Listed.

The most important one covers partly a wall of granite (facing towards the south) at the northwestern rim of the quarry, striking WNW-ESE and dipping, very steeply towards NNE (104/82 N). The bordering granite (opposite in the south) has been removed by excavation. The same concerns the sandstone dyke except of some remnants (see Fig. 2 for example).

This primary persistent sandstone is up to $10 \mathrm{~mm}$ thick. The bordering wall (in the north) shows a subplanar surface, only occasionally with weak sinuosities. At these points, curvatures on both sides of the sandstone filling are completely identical. Neither vertical nor lateral shiftings parallel to the dyke have taken place. This indicates an opening of the dyke by movements perpendicular to the bounding walls by pure extensional forces.

From the main dyke up to $15 \mathrm{~mm}$ thick wedge-shaped and therefore very short, subordinate dykes are branch- ing sub-perpendicularly into the granite on the northern side (Fig. 2). They are more or less curved, dipping mostly towards the east. The opening of these subsidiary dykes has apparently happened in connection with the extension of the main dyke by very weak block rotations in the northern hanging block.

Furthermore, ex remely thin, up to $3 \mathrm{~mm}$ thick sandstone dykes have been found in the northwest corner of the quarry. They are crossing the northern exit in a similar direction (109/89 $\mathrm{N}$ in average). The joints together with the sandstone fillings show extremely planar features. Here, the bordering joints - but not the fillings of the dykes - may have been induced by tensional forces and later on have been used during extensions.

The orientations of the main dyke as well as those of the dykes branching from this are drawn in the Schmidtnet lower hemisphere (Fig. 3 a). The pole projections of single strike-dip data from different points of the walls bordering the main dyke (dots) do not show random distribution. That underlines the above mentioned extremely straight streching horizontally and to the depth. The same can be said of the thinner dykes crossing the northern exit (Fig. 3 b), taking into account the farther distance of the measuring points.

The pole projections of the dykes branching from the main dyke (Fig. 3 a, crosses) are occupying a great circle (dashed-109/81 S) which hardly differs from the great circle projection of the main dyke (hatched-104/ $82 \mathrm{~N}$ ) in respect of striking, but is inclined to the south. Thus rotational axis of blocks (square) dips weakly to the north. The arrows on the great circle projection (dashed) indicate the tendencies of rotational move- 


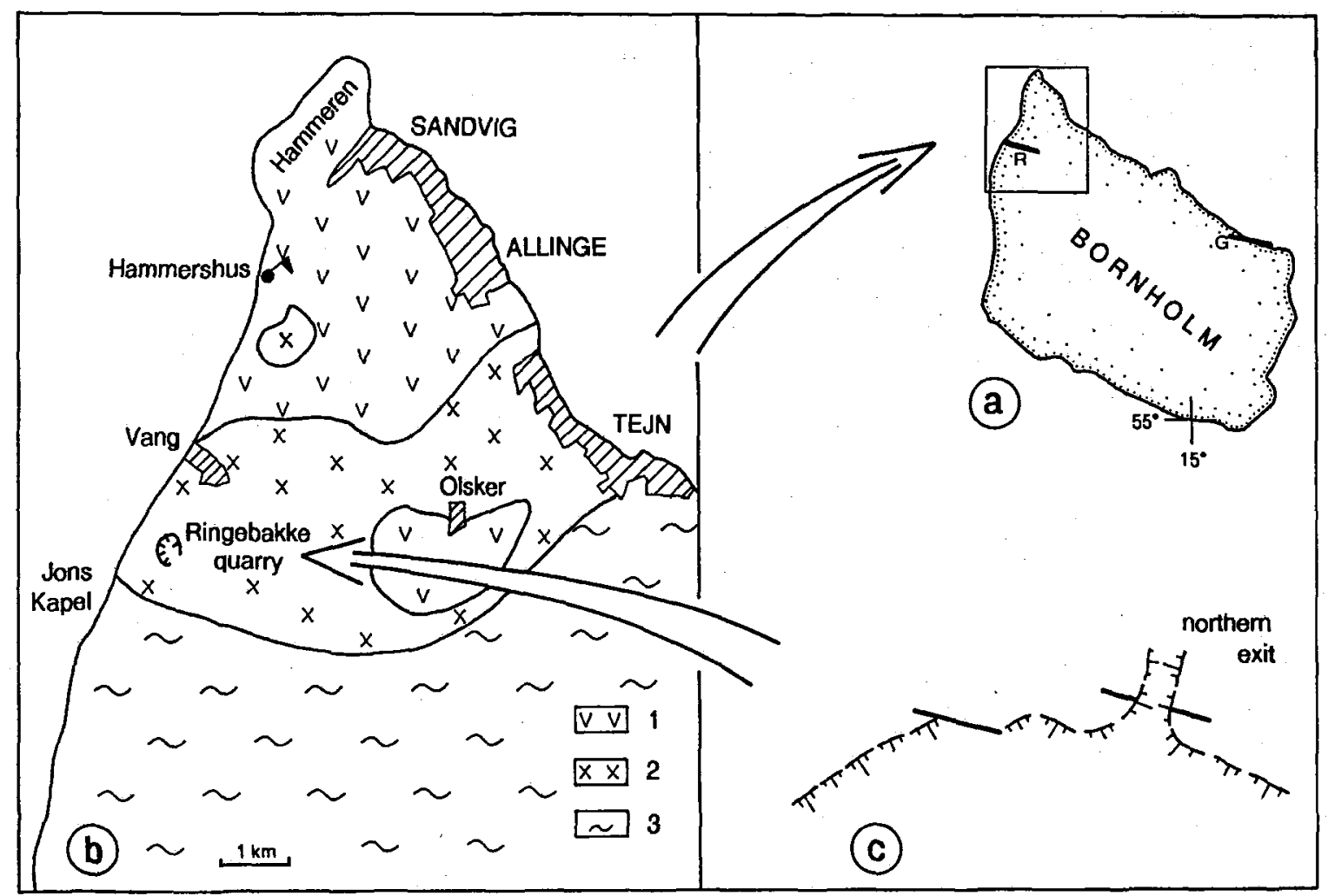

Fig. 1. Locality map. a) Bornholm with localities of sandstone dykes (thick lines indicate general strike) at Gule Hald (G) and Ringebakke (R) respectively, b) Northwestern Bornholm's geology: 1-gneiss, 2-Vang granite, 3-Hammer granite, c) Northwestern part of the Ringebakke quarry with the two sandstone dyke localities, indicated as in a) (not to scale).

ments on listric normal faults in the northern (hanging) block to the east (prevailing) and the west respectively, whereas open arrows outside (Fig. $2 \mathrm{a}$ and $2 \mathrm{~b}$ ) show extensional directions.

Taking into consideration the tilting of the Bornholm block as a whole of about 5 degrees SSW in late Mesozoic and early Tertiary times as a part of the Tornquist-Teisseyre Zone, an originally subvertical (inclination $90 \pm 5$ degrees) position of the main dyke at the western rim as well as that crossing the northern exit of the quarry can be assumed. From this, a horizontal extension in NNE-SSW- $\left(15^{\circ}-195^{\circ}-\right)$ direction (Fig. $3 \mathrm{~b}$ ), probably associated with doming of the northern Bornholm area, is the most reasonable explanation for opening of the pre-existing joints.

If the dating of the fillings of the Listed dykes is correct (Brunn-Petersen 1975), sandstone dykes on Bornholm as a whole (see Ussing 1899) indicate general N-S extensional forces in early Cambrian times, thus suggesting tectonic activities in and along the Tornquist-Teisseyre Zone earlier as thought up to now. They could have been caused by an upwarping of the south-west border of the Fennoscandian Shild during Cambrian-Ordovician times, as indicated by reduced thicknesses and enlarged stratigraphical gaps of the
Bornholm sucession in relation to that of Skåne. Apparently, this extension at the south-west border of Baltica has been connected with the opening of the Tornquist Ocean farther south between Baltica and Peri-Gondwana (see Servais \& Katzung 1993, Giese et al. 1994), at the passive margin of this ocean.

\section{Acknowledgment}

G. K. Pedersen and O. Vejbæk is thanked for helpfull hints.

\section{References}

Brunn-Petersen, J. 1975: Origin and correlation of the sandstone dykes at Listed, Bornholm (Denmark). Bulletin of the Geological Society of Denmark 24, 33-44.

Giese, U., Katzung, G. \& Walter, R. 1994: Detrital composition of sandstones from the Rügen boreholes: implications for the evolution of the Tornquist Ocean. Geologische Rundschau 83, 293-308.

Milthers, V. 1930: Bornholms Geologi. Danmarks Geologiske Undersøgelse (5) 1, $131 \mathrm{pp}$. 

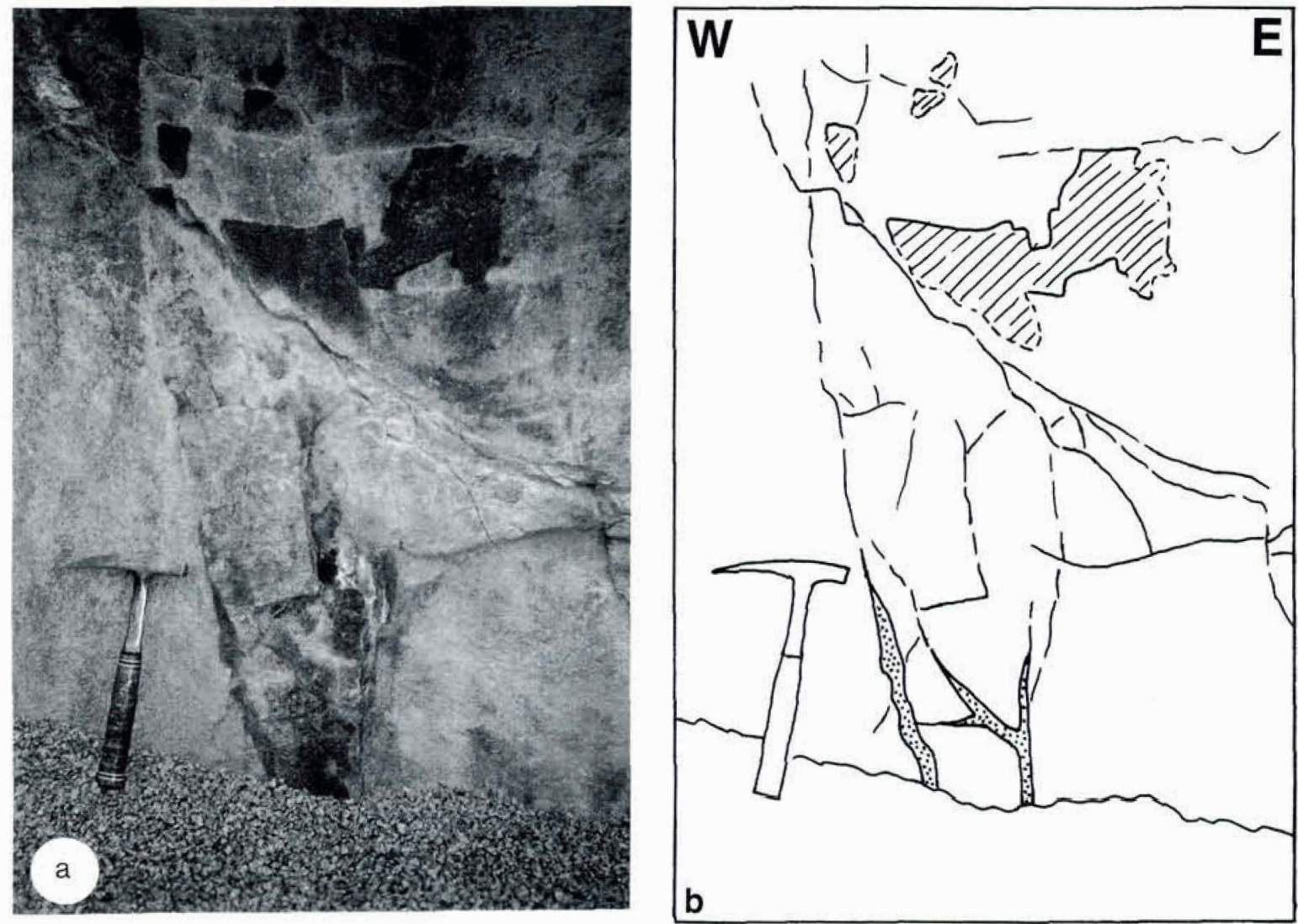

Fig. 2. Northern bordering wall (granite) of the sandstone dyke (remnants of it are shown by hatching) and subsidiary dykes (dots); a) photograph, b) drawing.

Servais, Th. \& Katzung, G. 1993: Acritarch dating of Ordovician sediments of the Island of Rügen (NE-Germany). Neues Jahrbuch für Geologie und Paläontologie, Monatshefte 1993, 713-723.

Ussing, N.V. 1899: Sandstengange i Granit paa Bornholm. Danmarks Geologiske Undersøgelse (2) 10, 87-98.

Fig. 3. Spatial orientations of sandstone dykes in the Ringebakke quarry. Schmidt-net lower hemisphere. Dots poles of main dykes; crosses poles of branching dykes; quadrangel - pole of rotational axis of tilted blocks; arrows - directions of rotation, a) Northwestern wall of the quarry, b) Northern exit of the quarry. For further explanations see text.
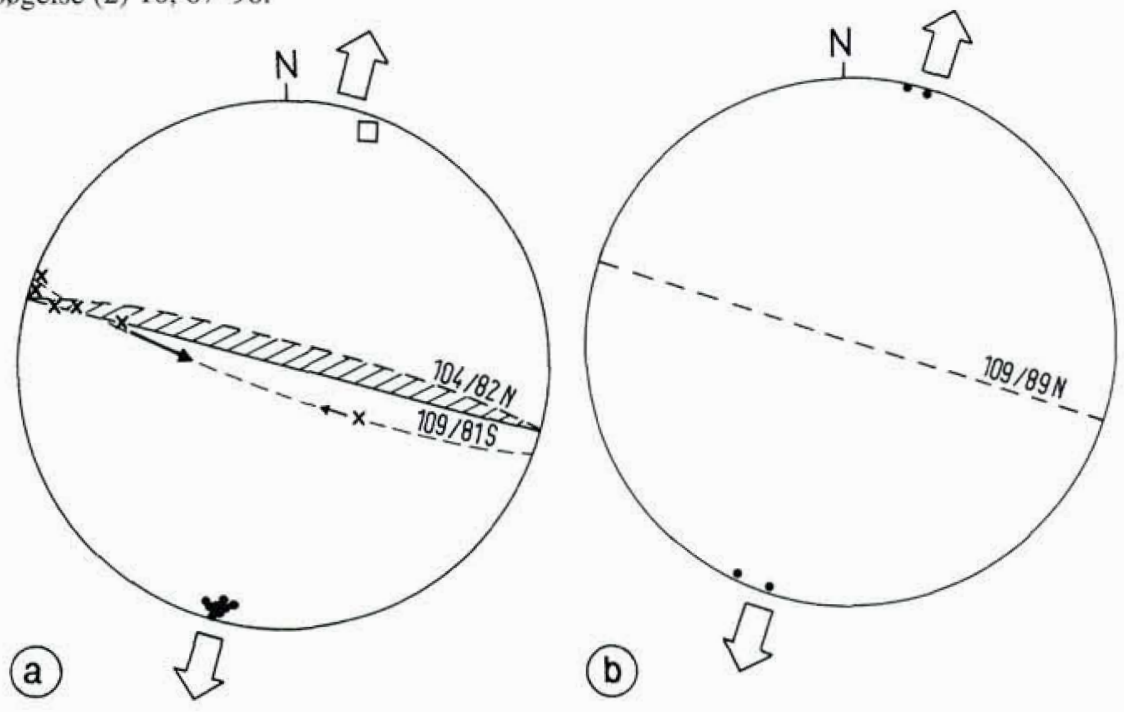